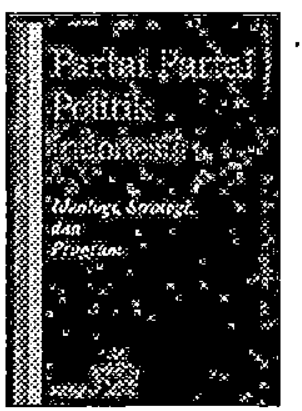

\author{
Buku : Partai Partai Politik di Indonesia \\ Ideologi, Strategi dan Program \\ Tim Litbang Kompas \\ Penerbit : PT Gramedia Jakarta \\ Tebal : 634 halaman
}

\title{
Partai Politik, Kemajemukan Tanpa Radikalisme
}

$\mathrm{R}$ angkaian proses pendirian partai politik, yang kini berjumlah 48 , menunjukkan betapa besar antusiasme masya-rakat untuk memulai kegiatan politik secara terbuka. Maklum saja, selama Orde Baru terjadi penindasan atas seluruh elemen dasar kebebasan berpolitik dalam masyarakat. Masa-masa dimana untuk mendeklarasikan sebuah perkumpulan selalu menerima resiko terancam dan jika tidak beruntung akan dijebloskan ke dalam bui. Pengalaman PUDI dan PRD menunjukkan kerasnya pendekatan keamanan dan kukuhnya ototerisme yang dipimpin oleh Soeharto. Kini, berangsur-angsur, aliran keberanian muncul dan sejak bulan Mei, hampir tiap minggu berdiri Parpol baru. Apapun motif maupun visinya, jelas memanfaatkan kebebasan adalah pendorong terbesar berdirinya sebuah partai politik.

Paling tidak ada tiga teori, yang mencoba menjelaskan asal-usul kehadiran Partai Politik. Pertama, adalah teori kelembagaan yang mengatakan bahwa partai politik dibentuk oleh kalangan legislatif (dan eksekutif) karena ada kebutuhan para anggota Parlemen (yang ditentukan berdasarkan pengangkatan) untuk mengadakan kontak dengan masyarakat dan membina dukungan masyarakat. Teori kedua menjelaskan, bahwa partai politik muncul saat sistem politik mengalami transisi karena perubahan masyarakat yang berstruktur sederhana menjadi masyarakat yang berstruktur kompleks. Perubahan diatas menghasilkan krisis, yakni legitimasi, integrasi dan partisipasi. Teori ketiga memandang bahwa modernisasi sosial-ekonomi mendorong lahirnya kebutuhan akan organisasi politik yang memadukan dan memperjuangkan pelbagai aspirasi. Jelasnya, teori ketiga memiliki kesamaan dengan teori kedua yang menyatakan bahwa pendirian sebuah partai politik berkaitan dengan munculnya perubahan.

Membicarakan Partai Politik, tentu harus terkait dengan ciri-ciri pokok keberadaanya. Seperti berakar pada masyarakat lokal, melakukan kegiatan secara terus-menerus, berusaha memperoleh dan mempertahankan kekuasaan dalam pemerintahan dan ikut serta dalam Pemilu. Paling tidak, 
ciri tiga yang terakhir ini dipunyai oleh hampir seluruh 48 partai, apalagi menjelang Pemilu. Pengalaman melukiskan dalam sistem politik Orde Baru, fungsi partai mirip dengan apa yang dilakukan oleh rezim fasis maupun komunis, yaitu memandang rakyat sosok yang harus dibina, diarahkan dan dimobilisasi demi tujuan-tujuan partai yang bergandeng dengan kekuasaan. Untuk itu politik penguburan massal partaipartai jadi kegiatan pokok yang dilakukan oleh Orde Baru pada awal berdirinya, seputar tahun 70-an. Kini, dengan paksaan dan desakan dari sejumlah mahasiswa, pintu liberalisasi berupa peng-efektifan hakhak politik tertentu yang dipunyai oleh individu maupun kelompok kembali dibuka lebar-lebar-

Adanya jaminan kebebasan berpolitik, menyulutkan harapan bahwa partai politik akan memaksimalkan fungsinya. Sebagai instrumen sosialisasi Politik di masyarakat, Partai bertanggung-jawab dalam pembentukan sikap dan orientasi politik para anggota masyarakat. Juga keberadaan Partai Politik, dapat menumbuhkan partisipasi politik masyarakat dalam menjalankan pengaruh maupun kontrol dalam pembuatan kebijakan di tubuh kekuasaan. Juga fungsi yang tak kalah pentingnya, adalah menampung dan memadukan berbagai kepentingan yang berbeda dalam masyarakat. Sebagaimana pengalaman Orde Baru, serangkaian fungși diatas akan tenggelam jika Partai Politik tidak mempertimbangkan beberapa ancaman yang mengintip dalam setiap pemerintahan transisi sekaligus pemerintahan yang masih satu kerabat dengan kekuasaan Soeharto.

Ancaman itu tak lain adalah, tingkat represi yang dijalankan kekuasaan yang sepenuhnya dikelola oleh aparatur militer. Ironisnya dalam buku ini, yang memuat sejumlah ideologi, strategi maupun program partai, mayoritas partai tidak mencantumkan agenda pencabutan Dwi Fungsi ABRI sebagai pangkal persoalan. Malahan, hampir mayoritas partai diam ketika ABRI masih dikasih jatah 38 kursi dalam Parlemen. Ketika ABRI yang kini berganti nama dengan TNI tidak mempunyai dan tidak merasa bertanggung-jawab terhadap kebijakan-kebijakan dari rezim sebelumnya, maka akan lebih mudah bagi mereka untuk lepas tangan dari transisi, dengan meriyatakan bahwa mereka hanya berkepentingan untuk melindungi nilai-nilai institusional mereka dalam hal stabilitas dan otonomi, serta jaminan bagi adanya ketertiban umum dan keamanan nasional. Dalam kasus-kasus serupa, kebijakan diatas akan mendorong Militer untuk tidak mau peduli pada aturan main politik asalkan kepentingan-kepentingan institusionalnya tetap terjaga. Artinya jika, soal Militer tidak dijadikan agenda, terutama agen-agen penindasnya tidak segera dimintai pertanggung-jawaban, akan terjadi peralihan, dalam bentuk kudeta maupun pengaruh kuat militer ke dalam Parlemen.

Jaminan perubahan juga tidak akan signifikan, selama Partai-Partai Politik tidak mencantumkan perubahan minimal pada aturan main ketata-negaraan khususnya UUD 45. Dalam buku setebal 634 halaman, sedikit bahkan bisa disebut tidak ada, Partai Politik yang mencantumkan pencabutan UUD 45 sebagai program pokoknya. Bentuk spesifik dari sebuah penciptaan tatanan yang demokratis, tak lain adalah adanya prosedur minimal yang secara regulatif mengatur perubahan-perubahan sistem Politik secara mendasar. Dalam sudut pandang yang lebih mendasar, sedikit Partai yang mencoba mengkritisi keberadaan sistem Politik Trias Politica. Bersamaan dengan itu, anehnya, beberapa Partai tambah mencantumkan balik ke UUDS 50 . Kiranya, harapan akan keberanian Partai mendekonstruksi sekaligus mencabut ta- 
tanan fundamental, hanya ada pada sejumlah kecil Partai, seperti PUDI dan PRD.

Mengacu pada kelemahan sistem ekonomi yang mempercepat ambruknya potensi ekonomi Indonesia, juga sedikit, Partai yang mengoreksi apalagi berani melepaskan diri dari jeratan sistem kapitalisme. Upaya membangun basis ekonomi kerakyatan, hanya utopia tatkala, proses kapitalisasi dari kekuatan pemodal yang berkedok dalam usaha multinational kelak akan menyerbu di tahun 2000 . Krisis pengangguran tak bisa diatasi hanya dengan menarik kembali para pemodal dan yang mencemaskan lagi, jika rangsangan investasi ditarik tanpa mempedulikan areal kerja kaum petani dan buruh yang selama ini mengalami marginalisasi. Tidak ada bahkan tak mungkin ada partai yang mencoba menaikkan agenda nasionalisasi atau meminta pertanggung-jawaban beberapa usaha asing atas kerja eksploitasi mereka selama ini. Beban ekonomi yang lumayan berat, nyatanya dipandang sebagai persoalan yang bersifat instrumental sehingga solusinya cenderung, tidak mengubah akar kebijakan melainkan mencoba untuk melakukan manuver penyelematan darurat.

Mengacu pada buku ini, keberhasilan Soekarno, menurut Hatta-sebagaimana dikutip oleh Daniel Dhakidae-adalah kemampuanya memberikan rumusan yang jelas tentang suatu masalah dan daya tembus pandanganya yang mendasar terhadap struktur kolonial (hlm 6). Kiranya buku ini memaparkan secara gamblang, lemahnya Partai dalam menjangkau berbagai persoalan mendasar dan tidak dipunyainya keberanian mendobrak pintu perubahan. Jika bisa dimaklumi, keadaan diatas, mungkin juga dilatari oleh sebab pendirian Partai. Beberapa partai, khususnya partai gurem akan melihat liberalisasi sebagai kesempatan untuk apa saja. Bisa dilihat dari minimnya jumlah politisi yang berkarakter, apalagi dalam pencalonan caleg dominanya unsur nepotisme. Semua itu jika dicari penyebab tak lain adalah tiadanya kultur yang menumbuhkan kehadiran kekuatan Politik yang radikal, berakar dan tumbuh dengan melalui ujian panjang. Semua ini akan memaksa kita untuk bersabar, melalui waktu yang niscaya akan lama, untuk memulai budaya berpolitik baru.

Membaca buku diatas kemudian melihat tampilan riil dari beberapa partai, kita jadi yakin, bahwa asas dan orientasi kebanyakan partai sangat pragmatis. Pragmatis dalam artian, program dan kegiatan dalam partai tidak terikat pada doktrin tertentu. Maksudnya perubahan waktu, situasi dan kepemimpinan bisa saja akan mengubah program, kegiatan dan penampilan partai tersebut. Ideologi yang ada pada $\mathrm{Par}$ tai semacam ini, merupakan sejumlah gagasan umum yang berasal dari serangkaian program maupun doktrin yang siap dilaksanakan. Sedang jika dipandang dari sisi komposisi maupun fungsi anggota, kebanyakan lebih memilih menjadi Partai Massa ketimbang Partai kader. Yang dimaksud derigan partai massa, partai yang mengandalkan kekuatan pada sejumlah anggota dengan mobilisasi massa sebanyakbanyaknya. Kelemahan partai semacam itu jelas, bahkan tampak sekarang ini pada, kemampuan anggota partai untuk menerima keputusan dari pimpinan Partai. Ancaman terbesar dari jenis partai diatas, adalah rawanya perpecahan dan mudahnya muncul kàder loncatan.

Jika ditilik dari pola ideologinya, tampaknya partai yang berjumlah 48 kebanyakan mengambil garis kanan. Adalah mereka yang lebih mudah untuk merundingkan berbagai kesepakatan secara kompromi sekaligus akan cenderung mentolerir beberapa prosedur aturan demokrasi. Saksikan saja, sedikit partai yang lantang pada isu federalisme, pengusutan kekayaan Soeharto 
apalagi militerisme. Kesepakatan dalam KPU yang banyak melanggar cenderung diakomodasi tidak ditolak secara lugas. Hal umum, yang dimuat pada buku ini, dengan diberi pengantar bagus oleh Daniel Dhakidae, telah berjasa mengenalkan pada pembaca kualitas Partai-partai ini. Jika mengambil kesimpulan, maka partai 48 ini hanyalah awal-mula dari guliran proses perubahan yang kelak akan terus berjalan. Se- tiap proses tidak saja membutuhkan waktu, kesaaran, dukungan melainkan juga kontrol sekaligus kritik. Buku ini mengantar pembaca untuk memilih, Partai mana yang berkarakter pecundang dan mana pula partai yang sungguh-sungguh. Sebuah pilihan tidak saja sulit tapi kadang juga keliru. Setidaknya, kita bisa bangga, mendapat pengalaman liberalisasi politik meski dengan hati cemas dan ongkos sosial yang tidak murah. Nikmatilah era Multi partai dengan segala resikonya. • 